undertaken and vigorously pressed. It requires first of all the valuation of the private property devoted to the public service and the determination of the private rights as to future returns. These matters should be settled once for all in every case, so that in future the facts would be constantly shown by the accounts and it would be a mere arithmetical task to fix the necessary increases or decreases in rates. But this requisite, together with others, has been discussed in previous articles and need not be further considered.

Proper regulation is a tremendous responsibility, but it can be carried out. It requires understanding, public vision, justice, common sense and forcible resolution and enterprise. Men with those qualities are available if we in. sist upon their selection. The rest is a matter of investigating facts, determining policies and providing adequate machinery and methods to carry out the public purposes, without injury to private rights. All this, to be sure, is the essence of successful regulation, but it can be achieved readily enough if only we have the right personal qualities on the commissions.

\title{
A REVIEW OF CITY PLANNING IN THE UNITED STATES, 1920-1921
}

\author{
BY THEODORA KIMBALL \\ Librarian, School of Landscape Architecture, Harvard University; Hon. Librarian, American \\ City Planning Instituto
}

The annual review by Miss $K$ imball reflects increasing activity in city planning and zoning. For example, more than thirty states now have laws relating to some phase of city planning. $\quad$ : $\quad:$ : : :

IT is gratifying to the writer, as to all those actively interested in city. planning in the United States, that there is far too much news of progress to be compressed into the space of a brief article. Ten years ago the term "city planning" was little known and less understood. In the last year or so, Ohio, Illinois, Indiana, Michigan, Minnesota, Missouri, Kansas, Texas, Tennessee, Connecticut and Rhode Island have passed laws relating to city planning and zoning.

The Massachusetts legislature will shortly be asked for a field secretary for the division of housing and town planning ${ }^{1}$ in the state department of public welfare. The Ohio State Conference on City Planning has an aggressive

1 First Annual Report for 1920. legislative program, adopted last October, to secure a comprehensive series of laws for Ohio.

The Realtors of California have been leading an educational campaign. Portland, Oregon, announces a successful gift campaign initiated by the mayor's proclamation, which secured 150 dedications for streets and parkways from public-spirited citizens in accordance with the city plan commission's major street plan.

To single out a few "high-spots" in individual municipalities, Philadelphia carried its $\$ 33,000,000$ loan ordinance for public improvements four to one and can point with pride to a remarkable precedent in the Fairmount Parkway; Cleveland approved by an overwhelming vote the tax levy for the ac- 
quisition and improvement of park lands by the Cleveland Metropolitan Park Board, and has added another unit to its civic center; and Chicago, St. Louis, and Detroit, each with an exceptional number of projects, are marching steadily on their well-blazed ways. Los Angeles reports that city planning has been put into all the high schools, the University of California, and the University of Southern California. Universities in several other states are offering extension lectures on town planning topics.

\section{PUBLICITY METHODS}

A considerable number of cities have recently introduced or are about to begin the study of city planning in the public schools, among them Johnstown, Akron, Cleveland, Detroit, Decatur, and Omaha.

Two cities, besides the ever active pioneer Chicago, are conducting educational campaigns among their adult citizens, which deserve special mention: Pittsburgh and Cleveland. ${ }^{1}$ These cities have distributed leaflets and fliers well calculated to attract, hold, and enlist their voters, by clever cartoon, succinct statement, and reasoned argument. Two committees of the City Planning Conference which reported at Pittsburgh had reference to publicity methods: one on moving pictures, and the other on the airplane in city-planning work.

\section{RURAL DEVELOPMENT AND THE GARDEN CITY IDEA}

An opportunity for a great national demonstration of agricultural community development on sound lines is set forth in Mr. Thomas Adams' report

\footnotetext{
1 Note especially: "The People's Business in the Fifth City" and "Zone Plan" (Cleveland) and "Progress" (Pittsburgh).
}

on the proposed farm city ${ }^{2}$ near Wilmington, North Carolina. Under the leadership of Mr. Hugh MacRea, agricultural colonies have already been successfully started in this region. The first convention of the Tri-State Development Congress (Michigan, Minnesota, and Wisconsin) included rural community planning in its program. ${ }^{3}$ Señor C. Montoliu has prepared a unique report for the single tax colony at Fairhope, Alabama. ${ }^{4}$

A plan of great interest, adapting the garden city idea to an existing American town, is Mr. John Irwin Bright's for Coconut Grove, Florida." This proposes a "productive park strip" owned by the municipality surrounding the heart of the town. The plan, discussed by Mr. Thomas Adams, ${ }^{6}$ seems less feasible under present American conditions, than Mr. Adams' new proposal to substitute "agricultural wedges" for "zones," following a discussion at the Baltimore meeting of the American City Planning Institute last winter.

\section{REGIONAL PROJECTS}

Several noteworthy examples of regional planning are in progress. Mr. Olmsted and $\mathrm{Mr}$. Comey have made a survey of the Main Line District of the Philadelphia region and prepared a comprehensive plan, including a metropolitan park system, ${ }^{7}$ in a report to the Main Line Citizens' Association.

\footnotetext{
${ }^{2}$ Farm Cities Corporation (Wilmington, North Carolina), Publication No. \&, January, 1921.

${ }^{3}$ Report of Proceedings, St. Paul, 1921.

4 See American City, April, 1921; also report in Enclaves of Single Tax, by Fiske Warren.

5 Journal of the American Institute of Architects, April, 1921.

${ }^{6}$ Journal of the American Institute of Architects, October, 1921.

${ }^{7}$ Brief digest and park map reproduced in City Parks Association of Philadelphia, combined thirty-first and thirty-second annual reports.
} 
The city of New York in co-operation with surrounding municipal and county authorities is planning a highway system for the whole metropolitan area, with the special advice of $\mathrm{Mr}$. Nelson P. Lewis. Most important of all to our national economy is the port treaty recently signed between the states of New York and New Jersey and approved by the federal government to encompass the comprehensive development of one of the great port areas of the world.

\section{COMPREHENSIVE PLAN REPORTS}

General plan reports have been issued for seven cities: Hamilton, ${ }^{1}$ Ohio; Decatur $^{2}$ and Joliet, ${ }^{3}$ Illinois; Newton, ${ }^{4^{\mathrm{a}}}$ and Gardner, ${ }^{\text {tb }}$ Mass.; Bristol, ${ }^{5}$ Connecticut; and Jersey City. ${ }^{6}$ Most of these reports show keen appreciation on the part of city planners of the importance of "selling" the plan through an attractive form of publication. The folio size and handsome illustrations of the Newton plan distinguish it. The Jersey City report is also fully illus-

1 The City Plan of Hamilton, published by Chamber of Commerce, 1920, Harland Bartholomew, city plan engineer.

2 The Decatur Plan, made for the City Plan Commission of Decatur by Myron H. West of the American Park Builders, 1920.

${ }^{8}$ City Plan of Joliet, by Edward H. Bennett and William E. Parsons, assisted by H. T. Frost, published by Joliet, City Plan Commission, 1921.

1. Report of the Planning Board, Newton, Massachusetts, September, 1921. Combined annual reports for 1919,1920 , and 1921 , including a special report upon a system of thoroughfares, parks, and playgrounds, by Arthur A. Shurtleff. and a zoning plan and ordinance, prepared by John P. Fox.

is Report to Planning Board, by Kilham, Hopkins and Greeley, 1921.

${ }^{3}$ Local Survey and City Planning Proposals for Bristol, Connecticut, by John Nolen, 1920.

- Jersey City Development Plan, prepared by direction of the Board of City Commissioners of Jersey City, 1920, by a board of engineers. trated. The Joliet report contains some fine renderings in color. Of special interest in the Hamilton plan is the section "Legal powers affecting the city plan of Hamilton," by Alfred Bettman, Esq., of Cincinnati.

The Wheeling, West Virginia, Improvement Association has issued some abstracts of reports on several phases of a city plan for Greater Wheeling.? Kansas City, Kansas, has had valuable advice from $\mathrm{Mr}$. Thomas Adams ${ }^{8}$ as to its future development. The combined annual reports for 1919 and $1920^{\circ}$ of the City Parks Association of Philadelphia is a live publication, stimulating to read, and an object lesson of what energetic foresight can accomplish.

The single volume containing the annual reports for $1915-1920^{10}$ of the Providence, Rhode Island, city plan commission shows zoning undertaken and realization by a wide-awake commission of the need for a comprehensive plan. The broad scheme in preparation for St. Paul is described in the $E n$ gineering News-Record for November 3, 1921. Many other cities have plans in preparation. One regarded with especial interest is Springfield, Massachusetts (Technical Addvisory Corporation and Olmsted Brothers).

The City Club of Portland, Oregon, has issued ${ }^{11}$ through its city planning bureau (E. T. Mische, chairman) a tentative City Plan of the West Side Flat.

\section{MAJOR STREET PLANS}

Portland's city planning commission issued in January, 1921, its Major

7 Morris Knowles, Inc., consultants, 1980.

${ }^{8}$ City Planning and City Building for Kansas City, Kansas, presented in report of Thomas Adams, and in address of A. D. Albert at annual meeting of the Chamber of Commerce, 1920.

9 31st and 3id.

$10 \mathrm{gd}$ to 7 th.

11 October, 1921. 
Traffic Street Plan, Boulevard, and Parli Sysiem, ${ }^{1}$ Charles H. Cheney, consultant, showing careful original study and also reference to previous city-planning work in Portland. The Cleveland Thorofare Plan $^{2}$ came out in the spring of 1921, excellent as publicity material as well as thoroughly studied.

The method of preparing the Major Street Plan of Pittsburgh ${ }^{3}$ is Wworthy of note. A sub-committee of the Citizens' Committee, with Messrs. F. S. Bigger and Harland Bartholomew as experts, thrashed it out patiently so that it represents to an extraordinary degree a consensus of opinion.

\section{CONTROL OF BTREET SYSTEMS}

The enforcement of a major street plan and the regulation of street location in residential subdivisions have continued subjects of live interest. The January, 1921, meeting of the American City Planning Institute was largely devoted to it, and the subject was again debated at Pittsburgh in May." Mr. Frank B. Williams' article, "Enforcing the City Plan," in the REview for July, 1921, is important. The city of New Bedford, Massachusetts, has an unusual and practical method of dealing with plats, the mayor and alderman constituting a board of survey. Rochester, New York York, has issued revised platting regulations.

\section{SPECIAL STUDIES}

A report ${ }^{5}$ of considerable interest comes from the Minneapolis Civic and

\footnotetext{
1 Bulletin No. 7 of the Commission.

2 Cleveland City Plan Commission, Robert

H. Whitton and Frank R. Walker, advisors.

${ }^{3}$ Issued by the Citizens' Committee on City Plan, September, 1921.

4 See Proceedings of the National Conference on City Planning, Pittsburgh, 1921.

s Issued in mimeographed form.
}

Commerce Association on street illumination, and contains a systematic analysis of street-lighting problems. A special park system report for a small Iowan city is that for Ottumwa prepared for the park board, 1920, by Mr. L. W. Ramsey.

A study of the Newtown Creek Industrial District of New York City, put forth by the Merchants' Association, 1921, shows the marked port terminal advantages of a still undeveloped district close to Manhattan.

\section{PORT TERMINAL DEVELOPMENT}

Undoubtedly the most important city planning document of the year is the Joint Report of the New York, New Jersey Port and Harbor Development Commission. After an exhaustive study, the commission, created in 1917 of eminent engineers, has presented a comprehensive plan and recommendations for the development of the whole waterfront area of Metropolitan New York. The commission sees the port problem primarily as a railroad problem, and believes that the carrying out of its comprehensive plans would go. far towards reducing the high cost of living not only locally, but in all parts of the country.

Subsequent to the inter-state commission's report, there has been issued an independent report, ${ }^{7}$ with different plans, by a New York City special committee headed by the chief engineer of the board of estimate and apportionment.

An inland waterway report of importance in the development of the lake port of Chicago was made in 1920 by Mr. Van Vlissingen to the City of

${ }^{6}$ Published in 1920, with maps, plans, illustrations, etc.

7 Preliminary Report concerning the Brooklyn-Richmond Freight and Passenger Tunnel, October 15, 1921. 
Chicago Committee on Harbors, Wharves, and Bridges. ${ }^{2}$ It advises favorably as to the feasibility of developing Calumet Harbor as a public terminal on the Lakes to Gulf waterway system.

\section{RAILROADS}

Two cities making progress in solving the railroad problem are Dallas and Los Angeles. Dallas has already accomplished much in track removal and elevation, according to the plans made by Mr. Kessler and the late Mr. John F. Wallace, and promoted by the Metropolitan Development Association. ${ }^{2}$ The railroad commission of California ordered on April 26, 1921, the Plaza Union Terminal Station for Los Angeles to be proceeded with. The exhaustive report ${ }^{3}$ of the chief engineer of this state commission, published in 1920, is the basis of procedure. It should be noted that the California railroad commission is an important city-planning agency, and one with exceptional powers to produce results.

\section{RAPID TRANSIT}

The St. Louis city plan commission has published another of its series of special studies, dealing with The St. Louis Transit System, Present and Future.

The transit commission of New York City, appointed under the acts of 1921 to relieve the intolerable situation in New York, has issued a statement and outline of plan of readjustment for the

1 Plan and report, Lake Calumet Harbor. 1920.

'See Engineering Newos-Record, October 20, 1921.

- Report on Railroad Grade Crossing Elimination and Passenger and Freight Terminals in Los Angeles.

1 Published 1920, Harland Bartholomew, consultant.
New York City street railroads, ${ }^{5}$ promising to publish shortly a general plan for building the new lines immediately required.

A recent report, ${ }^{6}$ prepared by the city engineer co-operatively with other officials of Seattle, proposed a rapid transit down-town subway loop for Seattle to provide for future growth. A rapid transit belt subway is under construction at Cincinnati at remarkably low cost owing to the exceptional topographic opportunities.

\section{HOUSING}

The United States Senate committee on reconstruction and production ${ }^{7}$ included in its report a recommendation for the establishment in the department of commerce of a division "for the gathering and dissemination of information as to the best construction practices and methods, technical and cost data, and matters relating to city planning, etc., in order to encourage standardization and improved building practices throughout the country." A division of building and housing (under the bureau of standards) has been established, with Mr. John M. Gries as chief, and advisory committees on building codes, plumbing (sub-committee), and zoning have been appointed by Secretary Hoover. The division is succeeding in securing co-operation from the producing industries which looks towards a decided improvement in the housing situation.

Mr. Veiller's revised Model Housing Law of 1920, with its many material changes, and Mr. Leifur Magnusson's Housing by Employers in the United States, long delayed in appearance as a bulletin ${ }^{8}$ of the United States bureau

${ }^{5}$ September $89,1921$.

$\checkmark$ Unpublished.

${ }^{7}$ 66th Congress, 3d session, Report No. 829.

${ }^{8}$ No. 263, October, 1980. 
of labor statistics, are both important to city planners.

\section{ZONING}

Zoning has taken the country by storm. Some of it is being done in advance of even preliminary comprehensive planning. It is expected that Secretary Hoover's advisory committee on zoning, consisting of Messrs. Lewis, Olmsted, Bassett, Veiller, Moses, Knowles, Ihlder, and McFarland will promote a sound knowledge of what zoning is and what steps should be taken to secure its advantages.

A comparison of recent compiled lists of zoned cities shows that nearly fifty have passed zoning ordinances and that about twenty states have enabling acts. Probably a hundred cities have zoning plans started, under way, or almost completed. The very valuable pamphlet by Mr. Bassett, The Board of Appeals in Zoning, gives a list with dates of the state and city laws, as an appendix to its lucid statement of the workings of this important piece of mechanism in the administration of a zoning ordinance. This pamphlet brings up to date Mr. Bassett's supplement to the Natronal Municipal Review for May, 1920. The October, 1921, Supplement to the REview gives more compiled information on The Law of Zoning, by Mr. Herbert S. Swan.

Any detailed analysis of zoning progress for 1920-21 would be impossible in the scope of this present article. A few of the printed reports which may be secured and examined may be mentioned,-for Pittsburgh ${ }^{1}$ and Evanston $^{2}$ (Bartholomew), Cleveland ${ }^{3}$ and Dallas $^{4}$ (Whitten), East ${ }^{5}$ and West

1 Issued by Department of City Planning.

2 Zoning Ordinance, 1921.

SThe Cleveland Zone Plan (tentative), report to the City Plan Commission, 1921.

- Proposed Zoning Ordinance, prepared by the
Orange," New Jersey (Technical Advisory Corporation, Ford), Cliffside Park, ${ }^{7}$ New Jersey (Swan), and San Francisco $^{8}$ (City Planning Commission). The second annual report of the Buffalo city planning committee of the council (Harry J. March, engineer) deals largely with zoning. The Omaha ordinance (Bartholomew) has not been published.

Zoning has been in operation in New York for five years. A striking effect of the zoning regulations is the far greater average of picturesqueness in the high buildings erected since 1916 . More imagination must go into their design, and thus to the city, through the exercise of the police power for welfare and safety, has come a new source of beauty.

\section{CIVIC ART}

A publication that brings forcibly to mind the advance in civic art in the last generation is the new Catalogue of Works of Art belonging to the city of New York, published by the art commission and covering the works acquired since its appointment in 1908. The well-chosen illustrations stand proof of the great service which art commissions may render to our cities and the pleasure which well-designed outdoor statuary and monuments may bring.

That we should not be afraid to work consciously for organic beauty

City Plan Commission and the Chamber of Commerce, Metropolitan Development Association.

sast Orange Commission on Building Districts and Restrictions. Tentative Report, November 12, 1920.

- West Orange Commission on Building Districts and Restrictions. Tentative Report, June 1, 1921.

${ }^{7}$ Zoning Ordinance and Building Code, 1921.

${ }^{8}$ Approved October 3, 1921. 
in city planning was the plea of Mr. Archilect, Planner of Cities, just pubGeorge B. Ford at the Pittsburgh city lished, ${ }^{1}$ we have revivified the work of planning conference. In a reaction American artists in producing a beaufrom the esthetic emphasis due to the tiful "white city" out of ugliness and real source of our American city planning movement - the World's Fair at Chicago - we seem to have swung too far. We have now a chance to refresh ourselves at the fountain source. In Charles Moore's Daniel H. Burnham, seeming impossibility, and in adapting to the twentieth century the nobly conceived but neglected plan of our capital city. The book is a great contribution to the cause of all civic art.

${ }^{x}$ Houghton Miffin Co., 1821. 2 volumes. 